\title{
Types of epileptic manifestations in pediatric patients
}

\author{
Tipologia manifestărilor epileptice în rândul populaţiei pediatrice \\ Mioara Cristina AVASILICHIOAEI ${ }^{1,2}$, Mihaela Adela IANCU ${ }^{1,3}$, Dumitru MATEI ${ }^{1,4}$ \\ ${ }^{2}$ Clinica Neurologie, Spitalul Clinic Colentina, București, România \\ ${ }^{3}$ Cabinet medical individual, București, România \\ ${ }^{4}$ Institutul Național pentru Sănătatea Mamei și Copilului „Alessandrescu-Rusescu“, \\ București, România
}

\section{ABSTRACT}

Epilepsy is one the most common serious neurological disorder and one of the reasons that patients visit family physician. Epilepsy in children, especially infants, differs from adults in the clinical manifestations of their seizures and in the presence of different electroencephalogram (EEG) patterns and etiologies. We inteded to provide an overview of the classification and etiology of diferent types of epilepsy in children. The existence of an algorithm of anamnestic, clinical elements, laboratory tests and medical imaging investigations by age groups is a useful tool for the family doctor in order to make an early diagnosis.
\end{abstract}

Keywords: epilepsy, children, clinical features

\section{REZUMAT}

Epilepsia este una dintre cele mai frecvente tulburări neurologice grave pentru care pacienții se prezintă la medicul de familie. Se descriu tipologii diferite de prezentare la copil, mai ales la sugar, față de adult, având diferite manifestări clinice, cu modificari pe electroencefalograma, cu etiologii diferite. Ne-am propus să oferim o imagine de ansamblu asupra clasificării și etiologiei diferitelor tipuri de epilepsie care se pot întâlni la copii. Existența unui algoritm de elemente anamnestice, clinice, teste de laborator și investigații de imagistică medicală prezentate pe grupe de vârstă reprezintă un instrument util pentru medicul de familie în vederea unui diagnostic precoce.

Cuvinte cheie: epilepsie, copii, tablou clinic

\section{INTRODUCERE}

Conform datelor puse la dispoziție în anul 2018 de către Organizația Mondială a Sănătății, aproximativ 2,4 milioane de persoane sunt diagnosticate anual cu epilepsie, iar la nivel global există în jur de 50 de milioane de oameni care suferă de epilepsie, aproximativ $80 \%$ dintre acestia provenind din țări cu un nivel scăzut sau mediu de venituri. Majoritatea poartă stigma bolii și sunt subiect de discriminare [1]. La o populație de aproximativ 7,6 miliarde, reiese că prevalența epilepsiei la nivel mondial este în jurul valorii de 6,5\%o, iar in- 
cidența în jur de aproximativ 32 de cazuri la 100.000 de locuitori. Cea mai mare incidență se întîlnește în rândul grupelor de vârstă corespunzând sugarilor și copilăriei timpurii, precum și în rândul grupelor de vârstă de peste 50-60 de ani, în timp ce prevalența este mică în rândul sugarilor și copiilor, crește la vârsta adultă timpurie și de mijloc, descrescând în anii târzii [1]. În ceea ce privește exclusiv populația pediatrică, studii metaanalitice au arătat că incidența medie $\mathrm{s}$-ar situa de fapt undeva în jurul valorii de $0,1 \%$, în țările dezvoltate aceasta fiind între 33,3 și 82 de copii cu vârste mai mici de 16 ani raportat la 100.000 de persoane pe an. Cea mai mare incidență se înregistrează în primul an de viață (între 81 și 130 de cazuri la 100.000 de locuitori), urmată de perioada copilăriei (50 la 100.000 de locuitori) și de perioada adolescenței (20 la 100.000 de locuitori, similar cu rata pentru adulți) [2]. Prevalența în rândul populației pediatrice pe de altă parte este în jurul valorii de $5 \%$ în țările dezvoltate și între 7,5 și $44,3 \%$ în țările în curs de dezvoltare [2]. Din punctul de vedere al etiologiei și al tipologiei manifestărilor epileptice, anumite studii [3] au arătat că epilepsiile cu etiologie necunoscută și cele cu crize generalizate înregistrează cea mai mare prevalență. În schimb, alte cercetări par a indica o ușoară predominanță a epilepsiilor focale comparativ cu cele generalizate, neexistând, în fapt, studii solid documentate cu privire la incidența sau prevalența tipurilor specifice de epilepsie sau a sindroamelor epileptice [4]. În ceea ce privește distribuția manifestărilor epileptice raportat la populația masculină sau feminină, ratele de incidență sau prevalență nu înregistrează diferențe de gen [5]. Pe de altă parte însă, atât incidența, cât și prevalența par să fie mai mari la nivel rural [4]. Din punct de vedere financiar, în Statele Unite, spre exemplu, costul direct anual al îngrijirilor medicale pentru epilepsie se ridică la 12,5 miliarde de dolari americani la 3 milioane de pacienți diagnosticați cu epilepsie [2]. Deopotrivă de importante sunt și aspectele psiho-sociale, având în vedere că în rândul adulților cu epilepsie cu debut în copilărie se înregistrează rate mai mari de șomaj, angajările făcându-se predilect în meserii mai puțin calificate, ratele de căsătorie sunt de asemenea mai mici, iar izolarea socială este mai frecventă comparativ cu grupurile echivalente din rândul populației generale, diferențele persistând chiar și în cazurile în care se obține remisiunea completă a crizelor [6].

\section{DEFINIȚII, CLASIFICARE}

O importanță deosebită în înțelegerea fenomenului este reprezentată de distincția dintre criza epileptică - 0 alterare temporară a funcției cerebrale ce rezultă dintr-un exces de activitate neuronală anormală - și epilepsie - boala propriu-zisă. Aceasta din urmă este definită pe trei paliere [5] ce includ pacienți cu:
- cel puțin două crize neprovocate sau reflexe separate de un interval de cel puțin 24 de ore;

- cel puțin o criză neprovocată sau reflexă și o probabilitate de peste $60 \%$ de a face crize ulterioare în următorii 10 ani (de exemplu cei cu leziuni structurale precum accident vascular, traumatism sau infecție cerebrală);

- una sau mai multe crize în contextul unui sindrom epileptic bine definit [5].

Aproximativ $10 \%$ din populație experimentează o criză epileptică izolată în timpul vieții [5]. În multe cazuri, etiologia epilepsiei este necunoscută, însă orice injurie ce perturbă funcția cerebrală ar putea declanșa o criză epileptică, printre acestea numărându-se modificările de structură (spre exemplu, malformații congenitale, traumatisme cerebrale, tumori, accidente vasculare), bolile infecțioase, bolile autoimune, defectele metabolice sau mutațiile genetice, până în anul 2018 fiind deja descoperite peste 500 de gene asociate epilepsiei [5]. Cea mai recentă clasificare clinică întocmită de Liga Internațională Împotriva Epilepsiei (International League Against Epilepsy - ILAE) împarte crizele epileptice în trei mari tipuri așa cum este ilustrat în figura $1[7,8]$ :

Cele focale, ce constituie aproximativ $60 \%$ dintre cazurile de epilepsie [5], debutează într-o zonă corticală restrânsă și pot fi precedate de simptome cunoscute sub numele de aură (precum senzații de teamă, senzații gastrice cu caracter ascensional, senzații olfactive etc.) - ele însele recunoscute de specialiști ca posibile manifestări de sine stătătoare ale unor crize focale [9]. Crizele focale se pot generaliza secundar la nivelul ambelor emisfere și pot fi urmate de simptome postcritice. Un exemplu tipic ar fi crizele motorii jacksoniene cu debut focal ce se pot răspândi în pată de ulei (marșul jacksonian), posibil cu generalizare secundară completă (criza tonico-clonică). Crizele primar generalizate, pe de altă parte, nu provin dintr-un focar originar uniemisferic, ci implică un debut în ambele emisfere cerebrale simultan, fără fenomene tip aură (exceptând crizele generalizate tonico-clonice în legătură cu care recent s-a constatat posibilitatea manifestării de aure) și cu posibil final brusc adesea neînsoțit de simptome postcritice [10]. Exemple din această categorie ar fi crizele de tip absență (denumite în trecut și petit mal) și cele tonico-clonice (denumite în trecut grand $\mathrm{mal}$ ). Cele de tip absență apar la copii, brusc, cu durată de aproximativ 10 secunde, cu întreruperea tuturor activităților motorii, cu excepția unora minore tip clipit sau plescăit și cu pierderea stării de conștiență, dar nu și a posturii. Cele primar generalizate tonico-clonice sunt uneori precedate, la câteva ore sau chiar zile înaintea crizei, de manifestări prodromale precum cefalee, modificări de apetit, insomnii sau iritabilitate și au un debut abrupt, manifestat printr-un țipăt (rezultat al 

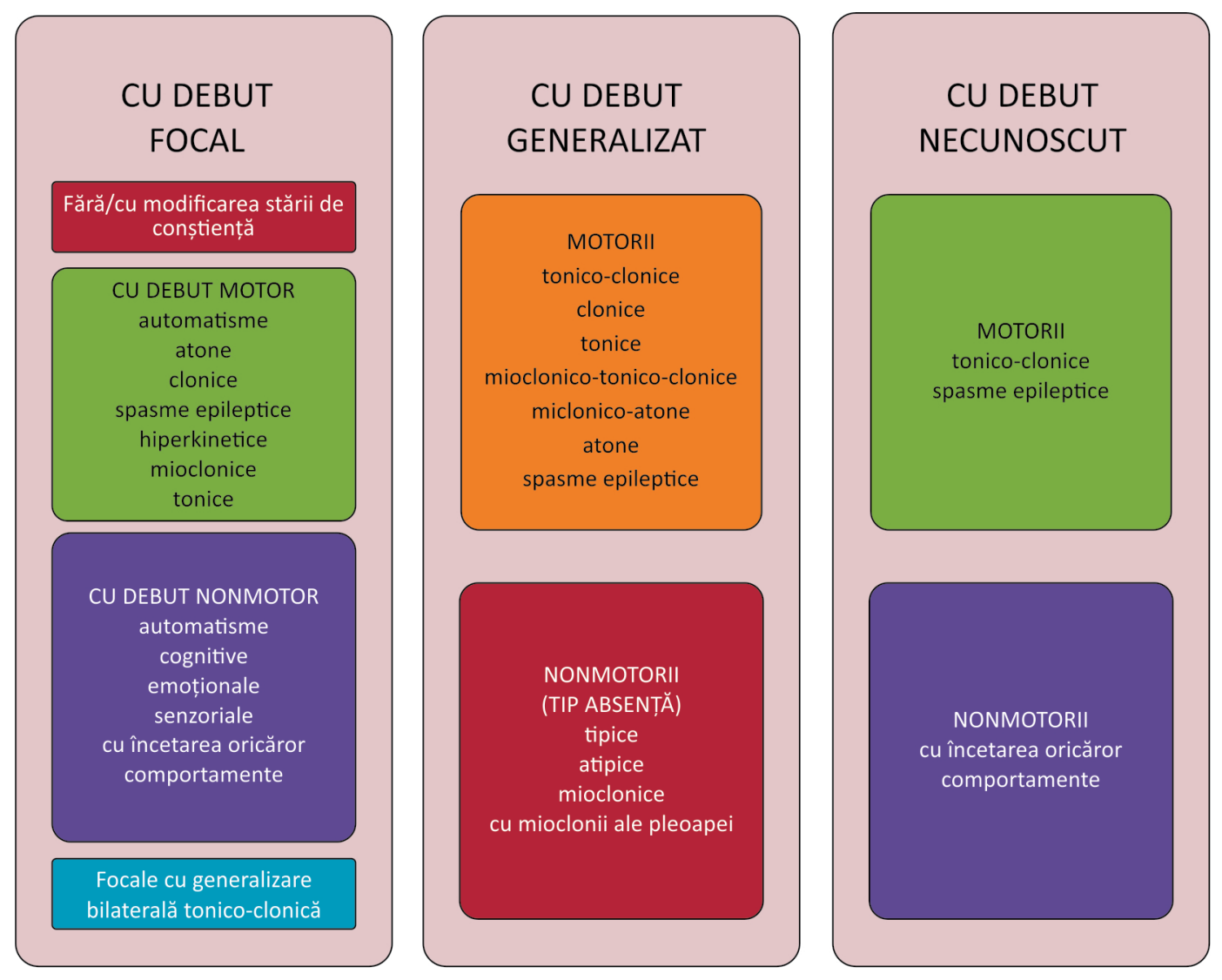

FIGURA 1. Crizele epileptice conform clasificării ILAE 2017 [7,8,12]

contracției tonice a diafragmului ce forțează expirul), cu o fază tonică de aproximativ 30 de secunde însoțită de rigiditate posturală, încleștare maxilară, pierderea funcției sfincterelor vezicale și/sau anale, hipersalivație, diaforeză, hipertermie și cianoză, urmată de o fază clonică de aproximativ 1-2 minute cu mișcări ritmice ale extremităților). Postcritic, aceste crize sunt caracterizate de o respirație stertoroasă, confuzie sau agitație, cu durată de 1-30 minute [10].

\section{TIPOLOGIA MANIFESTĂRILOR EPILEPTICE ÎN RÂNDUL POPULAȚIEI PEDIATRICE}

Încadrarea manifestărilor epileptice paroxistice într-o tipologie sau într-un sindrom presupune parcur-

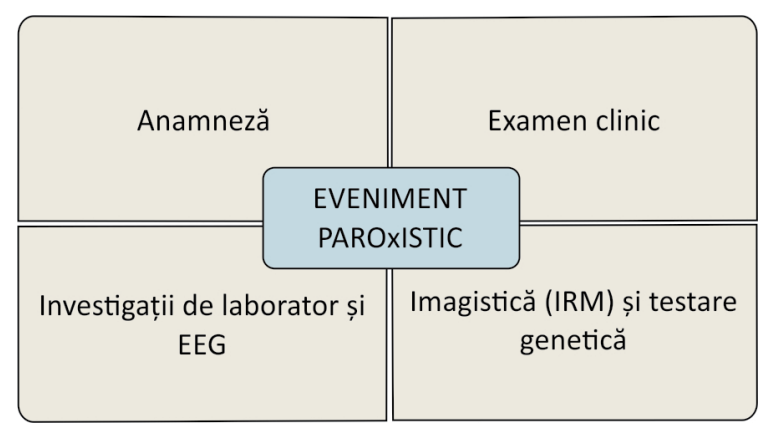

FIGURA 2. Cele 4 operațiuni de bază pentru elucidarea parametrilor tipologici şi etiologici ai manifestărilor epileptice gerea unui demers ce are la bază, într-o formulare simplificată, patru operațiuni agregate în jurul a patru pași diagnostici. Cele patru operațiuni (figura 2) includ anamneza, examenul clinic, și examinarea paraclinică de rutină sau mai avansată [5].

Cei patru pași diagnostici sunt ilustrați în figura 3 în succesiune logică [5].

Înainte de a considera în detaliu datele la zi din literatura de specialitate privind tipologia evenimentelor epileptice și sindroamele conexe, în special în rândul populației pediatrice, ar fi utile câteva precizări practice legate de cele patru operațiuni ale matricei diagnostice ilustrate mai sus.

\section{ANAMNEZA}

Din punct de vedere anamnestic, este esențial ca pacientului și/sau aparținătorilor acestuia să li se adreseze întrebări despre potențiale crize anterioare manifestării pentru care se prezintă pentru prima oară la medic (aceasta din urmă fiind adesea un eveniment tonico-clonic). Probarea anamnestică a unor asemenea evenimente precedente ar conchide practic cazul în direcția epilepsiei, corespunzător definiției ce presupune existența a cel puțin două crize neprovocate sau reflexe spațiate de un interval de cel puțin 24 de ore. Printre tipurile de crize mai greu recognoscibile se 


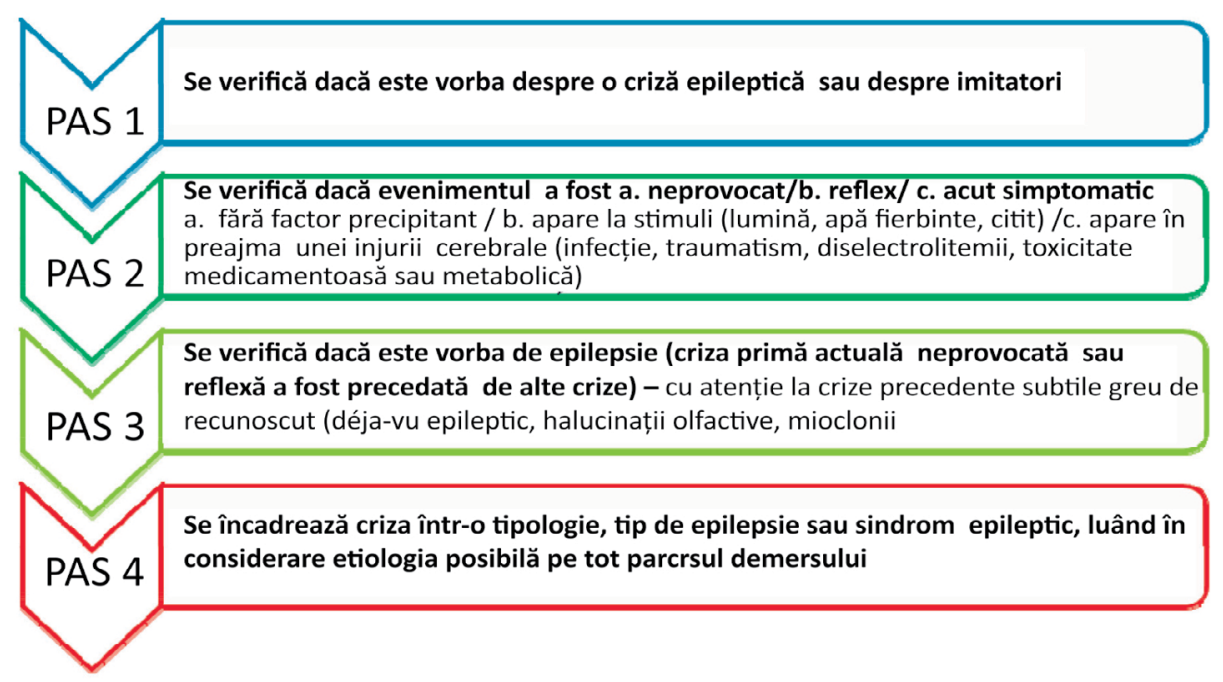

FIGURA 3. Cei patru paşi de urmat în diagnosticul unei manifestări epileptice

numără cele cu manifestări intense de déja-vu (cu mențiunea că cele epileptice diferă de cele fiziologice prin aceea că durează mai mult - tipic peste 5 secunde - sunt mai intense, neplăcute și necontrolabile de către pacient), cele cu senzații epigastrice cu caracter ascensional, halucinații olfactive sau gustative sau dificultăți de limbaj de scurtă durată, precum și crizele tip absență sau mioclonice. Există studii ce arată faptul că, dintre pacienții ce s-au prezentat pentru o criză epileptică, 11,3\% mai avuseseră o criză înainte de momentul prezentării, iar $29,5 \%$ chiar două sau mai multe crize. Este important de reținut și că timpul scurs între o criză nerecunoscută ca atare și criza de la momentul prezentării poate acoperi un spectru larg de durate de la câteva săptămâni la decenii [5]. În afara întrebărilor despre crize precedente, pacienții trebuie chestionați cu privire la circumstanțele imediat premergătoare unei crize, cele de la debut, din timpul, precum și cele ce au urmat evenimentului ce a ocazionat prezentarea la medic. Aceste întrebări pot orienta asupra caracterului focal sau generalizat al unei manifestări epileptice. Cele generalizate se prezintă cu pierderea stării de conștiență la debut, în timp ce majoritatea evenimentelor greu recognoscibile de tipul celor enumerate mai sus, la care s-ar adăuga automatismele prelungite orale sau manuale, posturile distonice ale membrelor unilateral, devierea forțată într-o anume direcție a capului sau a ochilor, mișcările bruște ale membrelor, asimetric sau unilateral, ce apar în timpul unei crize trimit practicianul cu gândul mai degrabă pe pista unei tipologii focale. Este de la sine înțeles că anamneza trebuie să includă întrebări despre evenimentele prenatale, reperele de dezvoltare, dificultățile de învățare, antecedentele familiale legate de epilepsie, convulsii febrile sau alte afecțiuni din spectrul autismului sau al altor afecțiuni psihiatrice, precum și întrebări legate de frecvența evenimentelor paroxistice, de factorii precipitanți, perioadele libere de evenimente, durata evenimentului sau vârsta la debut [5]. În cazul pacienților pediatrici cunoscuți cu tumori cerebrale în tratament, sunt necesare întrebări referitoare la tipul de medicamente utilizate, cunoscut fiind faptul că există o asociere între manifestările epileptice și terapia cu metotrexat sau faptul că medicamente precum cisplatina sau vincristina scad pragul necesar declanșării unei crize epileptice, ambele trecând bariera hematoencefalică și inducând crize secundar hipocalcemiei, hipomagneziemiei sau hiponatriemiei [11]. Elementele de anamneză ar trebui să orienteze deja asupra caracterului epileptic sau de imitator al unei crize. Printre imitatorii recunoscuți (ILAE; 2018) se află câteva clase mari de afecțiuni cu subcomponentele lor, după cum urmează [12]:

- sincopa și crizele anoxice (sincopa vasovagală; crizele anoxice reflexe; spasmul hohotului de plâns; sincopa prin hiperventilație; manevra Valsalva compulsivă; sincopa neurologică; sufocarea; intoleranța ortostatică; sindromul de QT lung și sincopa cardiacă; crizele hipercianotice)

- afecțiuni comportamentale, psihologice și psihiatrice (reveria/neatenția, autogratificarea, imageria eidetică, crize de furie; experiențe extracorporale; atacuri de panică; stări disociative; crize nonepileptice psihogene; halucinații; boală fictivă)

- afecțiuni ale somnului (afecțiuni motorii ritmice legate de somn; mișcări bruște hipnagogice; parasomnii; afecțiuni ale somnului REM; mioclonii neonatale benigne în somn; mișcări periodice ale membrelor inferioare; narcolepsie-cataplexie)

- afecțiuni motorii paroxistice (ticuri; stereotipii; diskinezii kinesigenice sau nonkinesigenice paroxistice; diskinezii paroxistice induse de activi- 
tatea fizică; privirea tonică în sus benignă paroxistică; ataxie episodică; hemiplegie alternantă; hiperekplexie; sindrom opsoclonus-mioclonus)

- afecțiuni asociate migrenei (migrena cu aură vizuală; migrenă hemiplegică familială; torticolis paroxistic benign; vertij paroxistic benign; emeză ciclică)

- diverse alte evenimente (miocloniile benigne ale sugarului și atacurile frisonante; starea de neliniște motorie; sindrom Sandifer; căderi nonepileptice ale capului; spasmus nutans; presiune intracraniană crescută; sindrom dureros extrem paroxistic; mioclonus spinal).

\section{DIAGNOSTICUL DIFERENȚIAL}

Pentru diagnosticul diferențial cu imitatorii crizelor epileptice - cum ar fi, spre exemplu, crizele nonepileptice psihogene ce constituie aproximativ 30\% dintre toate evenimentele paroxistice nonepileptice la copii - ar fi utile întrebări care să surprindă indicii clinic orientative precum mișcările geotropice ale globilor oculari odată cu întoarcerea capului, închiderea ochilor sau vorbitul șoptit postcritic în cazul crizelor psihogene versus cefalee sau frecatul nasului (ipsilateral focarului epileptic) postcritic în cazul crizelor epileptice [13]. Întrebările despre elemente declanșatoare precum ortostatismul prelungit, deshidratare, emoții puternice însoțite de manifestări autonome cum ar fi diaforeza, greața sau disconfortul abdominal orientează către sincopa vasovagală, în timp ce stimulii cu apariție bruscă precum loviturile la cap sau o tăietură trimit cu gândul la crizele anoxice reflexe. Spasmul hohotului de plâns este întotdeauna legat de un eveniment neplăcut, însoțit de plâns, cu oprirea respirației în expir și cianoză. O cianoză pronunțată observată de părinți, precipitată de tahipnee sau deshidratare, caracterizează crizele hipercianotice din tetralogia Fallot. Dacă evenimentul este întotdeauna observat de una și aceeași persoană acest lucru poate ridica suspiciunea sufocării ca formă de boală fictivă, iar un istoric familial de sincopă sau moarte subită poate orienta asupra unui sindrom de QT lung. În sfera tulburărilor psihice, întrebările despre posibilitatea de a distrage atenția copilului când acesta pare nemișcat, cu privirea fixă, orientează mai degrabă către stări de reverie, iar o descriere a crizei ca având mișcări ritmice cu flexia și adducția coapselor îndrumă către autogratificare. Copiii care au privirea fixă și par a vorbi fără a vocaliza cu personaje inexistente și care mișcă unul sau mai multe membre timp de câteva minute, manifestând furie dacă părinții le întrerup contactul cu lumea imaginară, suferă mai probabil de imagerie eidetică. În cazul crizelor de furie, sunt utile întrebările despre durata și conținutul acestora având în vedere că, spre deosebire de crizele epileptice, durează mult mai mult (peste jumătate de oră) și sunt mai puțin stereotipe. Experiențele extracorporale, în care pacienții raportează pierderea contactului cu propriul corp, putându-se vizualiza pe sine de deasupra, au fost relatate în cazuri de crize epileptice, crize anoxice sau în timpul migrenelor. Dacă unei senzații de teamă intensă (ce poate să apară și în cadrul crizelor epileptice focale) i se adaugă și senzații de sufocare, palpitații, dureri precordiale, parestezii tipic periorale sau la nivelul mâinilor, amețeală, diaforeză sau tremor, este mai probabil vorba despre un atac de panică. Comparativ cu halucinațiile din epilepsiile focale caracterizate de senzații elementare, cele psihiatrice sunt complexe, multi-senzoriale, pacientul văzând personaje sau auzind voci sau muzică. În privința tulburărilor de somn sunt esențiale întrebări despre etapa de somn când apar manifestările, durata și stereotipiile implicate. Duratele mai lungi și manifestările care nu sunt întocmai stereotipe de la o criză la alta îndepărtează medicul de prezumția unei crize epileptice. Alte întrebări utile sunt legate de atingerile sau zgomotele de nivel normal ce pot declanșa reacții exagerate de tresărire (hiperekplexie), care pot fi reproduse de examinator printr-o simplă atingere a vârfului nasului cu degetul și sistate (în caz de mare severitate) prin manevra Vigevano de flectare a trunchiului și gâtului copilului. Relatarea apariției unor crize (distonii ale membrelor, înclinarea capului) în timpul sau imediat după masă, la copiii cu reflux gastro-esofagian orientează către sindromul Sandifer. Nu în ultimul rând, dacă sunt menționate crize cu debut la schimbarea scutecelor, la defecație, la igienizarea zonei perineale sau în timpul mesei cu declanșarea unei dureri insuportabile însoțită adesea de eritem pe o singură parte a corpului (fenomenul arlechin), atunci este vorba, mai probabil, de sindromul durerii paroxistice extreme [12].

\section{EXAMENUL CLINIC}

Printre elementele de examen clinic ce ajută la realizarea diagnosticului pozitiv și diferențial se numără semnele de mușcare a limbii pe partea laterală a acesteia, ce trimit către o criză epileptică, spre deosebire de sincopă, în care ar putea fi afectat vârful mai degrabă decât partea laterală a limbii. Sunt, de asemenea, importante trăsăturile dismorfice ce orientează către sindroame genetice precum cele din sindromul Down (care se asociază cu spasme infantile) sau asimetriile membrelor sau ale mărimii unghiilor care trimit către un posibil accident vascular perinatal asociat cu crize focale. Dintre semnele evidente din sfera sindroamelor neurocutanate asociate cu epilepsii, pot fi amintite angiofibroamele faciale, fibroamele periunghiale, maculele hipomelanice și petele Shagreen din sindromul sclerozei tuberoase, petele faciale de culoarea vinului de Porto urmând teritoriul de distribuție al nervului 
trigemen din sindromul Sturge-Weber sau petele caféau-lait și hamartoamele de la nivelul irisului în neurofibromatoză [5]. Creșterea excesivă doar a anumitor segmente ale schemei corporale ar trebui să pună medicul în gardă cu privire la hemimegalencefalie sau, în cazul în care se asociază și sindactilia degetelor 2-3 de la picior și laxitate tegumentară și ligamentară, la sindromul megalencefalic-capilar. În cazuri mai rare, episoade scurte, dar frecvente, de râs mecanic (crize gelastice), posibil însoțite de pletoră facială sau dilatare pupilară, precum și de un comportament agresiv, anxietate sau pubertate precoce, trimit către diagnosticul prezumtiv de hamartom hipotalamic. La capătul sever al spectrului semiologic, o hemipareză inițial ușoară, însoțită de afazie expresivă sau deficit de câmp vizual și declin cognitiv progresiv, ar trebui să ridice suspiciunea de sindrom Rasmussen, cunoscut și drept epilepsia parțială continuă (cronic progresivă) a copilului, o inflamație unilaterală a cortexului cerebral [14].

\section{INVESTIGAȚIILE PARACLINICE}

În privința investigațiilor de laborator, pe lângă testele de rutină precum hemogramă, ionogramă și nivelul glicemiei, efectuate chiar și în ambulator, uneori se impune efectuarea unei puncții lombare și a screening-ului toxicologic. Relativ recent, în contextul descoperirii etiologiilor autoimune, au căpătat importanță determinările de autoanticorpi, dintre care ar putea fi amintiți anticorpii anticanal de potasiu voltaj-dependent, anticorpii anti-receptor NMDA sau autoanticorpii proteinei 1, bogată în leucină și inactivată de gliom (ultimii în cazul celor ce se prezintă cu crize distonice facio-brahiale și deteriorarea memoriei) [5]. De mare importanță, prin aceea că, în unele cazuri, terapia poate corecta defectul cauzator, sunt investigațiile ce țintesc erorile metabolice ce apar mai frecvent în perioada neonatală până către finalul copilăriei timpurii. Erorile în cauză acoperă o plajă foarte vastă de posibilități, de la boli legate de oxidarea acizilor grași sau de metabolismul aminoacizilor și al acizilor organici la boli mitocondriale, afecțiuni ale ciclului ureei, ale homeostaziei glucozei, afecțiuni vitaminice sau ale metabolizării neurotransmițătorilor, defecte purinice sau pirimidinice, boli ale peroxizomilor, tezaurismoze sau leucodistrofii. Investigațiile pe linie metabolică ar trebui să fie prilejuite de manifestări epileptice cu care sunt raportate asocieri mai frecvente, cum ar fi miocloniile, spasmele infantile sau chiar - în deficiența de transportor de glucoză - crizele de tip absență [15]. Despre EEG, pe de altă parte, este imperativ de menționat faptul că un traseu cu aspect normal nu exclude diagnosticul de epilepsie și că un aspect anormal nu este diagnostic pentru epilepsie în absența unui istoric relevant. De asemenea, este important și faptul că un traseu EEG intercritic se poate asocia cu rezultate falspozitive sau fals-negative ( $5 \%$ dintre copii au activitate epileptiformă fără să aibă vreo manifestare clinică, iar aproximativ $40 \%$ dintre copiii cu epilepsie cronică nu au activitate epileptiformă intercritică). În plus, chiar dacă un traseu EEG poate permite încadrarea într-un sindrom, traseele se pot modifica în timp sau pot genera informații contradictorii [2]. Cu aceste mențiuni păstrate vii în gândirea medicală asociată alcătuirii unui diagnostic, algoritmul de urmat pentru maximizarea șanselor de a depista descărcări epileptiforme ar fi cel expus în figura 4 [5].

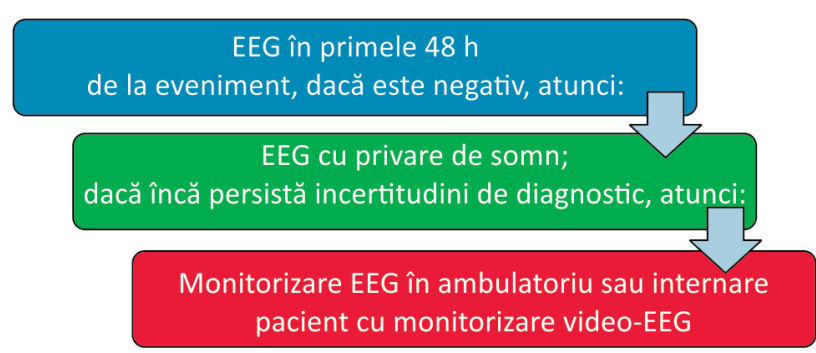

FIGURA 4. Algoritm de investigații EEG

Din punctul de vedere al investigațiilor imagistice, cele prin rezonanță magnetică sunt de primă intenție, fiind recomandate în rândul majorității pacienților cu o primă criză, cu excepția celor cu epilepsii generalizate tip absență a copilăriei sau epilepsie mioclonică juvenilă. Printre leziunile epileptogene detectabile prin IRM se numără injuriile cerebrale pre- sau perinatale, malformații de dezvoltare corticală, tumori, anomalii vasculare, scleroza hipocampică și encefalomalacia postaccident vascular sau posttraumatică [5]. În legătură cu manifestările epileptice posttraumatice, este utilă distincția dintre cele timpurii (ce apar în primele 7 zile de la evenimentul traumatic) și cele tardive - primele apărând mai frecvent la copiii cu vârsta mai mică de 7 ani, iar celelalte fiind asociate cu consecințe nefaste pe termen lung, riscul pentru ambele crescând cu severitatea traumatismului. În ceea ce privește accidentele vasculare, cele ce asociază manifestări epileptice târzii (după 7 zile de la producerea accidentului vascular cerebral) sunt asociate cu un risc mare (85,7\%-100\%) de recurență la copii. Nu în ultimul rând, testarea imagistică poate depista tumori cerebrale la aproximativ 1-3\% dintre copiii cu crize nou apărute, crizele putând să preceadă instalarea altor simptome cu câțiva ani. Tipurile de tumori asociate cu cel mai mare risc de crize epileptice sunt tumorile neuroepiteliale disembrioplazice și glioamele de grad mic [11]. Testarea genetică este utilă în special în cazul encefalopatiilor epileptice, precum și la stabilirea etiologiei unor epilepsii focale sau în cazul unor decizii de tratament (de exemplu, depistarea unei mutații SCN1A la un pacient cu epilepsie de lob temporal necesită întreruperea tratamentului cu carbamazepină, me- 
dicație ce poate înrăutăți crizele în cazul prezenței acestei mutații) [5].

Înainte de a trece în revistă tipurile de manifestări epileptice aferente fiecărei grupe de vârstă din rândul populației pediatrice, o mențiune specială este necesară în legătură cu convulsiile febrile, care, deși în afara spectrului epileptic prin natura acut-provocată a acestora, sunt, probabil, cele mai frecvente tipuri de crize convulsive pe care medicul de familie le-ar putea întâlni în rândul populației pediatrice. În legătură cu aceste tipuri de convulsii, este util de precizat faptul că apar la cel puțin 2-5\% dintre copii [16]. Populația pediatrică cu susceptibilitate mai mare la a dezvolta crize convulsive febrile acoperă spectrul de vârstă între 1 lună și 5 ani, cu un vârf de incidență la vârsta de 18 luni pe fondul unor temperaturi corporale de peste $38,3^{\circ} \mathrm{C}$ ce se pot instala înainte sau după manifestarea crizei. Crizele pot lua două forme - simple (izolate, generalizate și de scurtă durată), în cea mai mare parte a cazurilor, sau complexe (focale, multiple în timpul uneia și aceleiași boli febrile, cu durată prelungită de peste 10-15 minute, cu posibilitatea instalarii, la peste 30 de minute, a statusului epileptic febril). Din punct de vedere fiziopatologic, mecanismele sunt încă neelucidate, însă cercetările au arătat faptul că gastroenterita se asociază cu o incidență scăzută a crizelor febrile, în timp ce in- fecțiile cu virusul herpetic uman (în special cu tipul 6B) se asociază adesea cu status epileptic febril [16]. Dintre cei $2-5 \%$ copii ce dezvoltă crize febrile, doar o mică parte (între $2 \%$ și 10\%) vor dezvolta ulterior epilepsie, adesea în corespondență de formă de 1:1 (criză febrilă generalizată - epilepsie generalizată; criză febrilă focală - epilepsie focală), printre factorii de risc numărându-se anomaliile de neurodezvoltare, convulsiile complexe, istoricul familial de epilepsie și durata febrei. Este însă important de menționat și faptul că există unele sindroame specifice (de exemplu epilepsia mioclonică severă a sugarului) a căror primă manifestare poate lua forma convulsiilor febrile [16].

Dintre tipurile posibile de manifestări epileptice și combinații ale acestora în sindroame electroclinice, se remarcă câteva a căror frecvență sau al căror prognostic justifică o atenție amănunțită. Sindroamele electroclinice sunt constelații de tipuri specifice de crize sau manifestări epileptice, cu modificări tipice ale traseului EEG și cu apariție la anumite etape de vârstă, constelații ce prefigurează prognosticul și ghidează opțiunile de tratament. În tabelele 1-4, se regăsește sinteza celor mai importante trăsături ale acestor sindroame, grupate pe categorii de vârstă de la perioada neonatală la perioada adolescenței și marcate cu \# în cazul unui prognostic favorabil și cu \& în cazul unui prognostic infaust.

TABEL 1. Sindroame cu debut neonatal [17]

\begin{tabular}{|c|c|c|c|c|c|c|}
\hline Sindrom & Vârf incidență & Tip criză & EEG & Etiologie & Prognostic & Tratament \\
\hline $\begin{array}{l}\text { \# Convulsii } \\
\text { neonatale } \\
\text { benigne }\end{array}$ & $\begin{array}{l}\text { ziua 4-6; } \\
\text { "criza de ziua } \\
\text { a cincea" }\end{array}$ & $\begin{array}{l}\text { unifocală clonică } \\
\text { (rar tonică); 1-2' } \\
\text { sau SE }\end{array}$ & $\begin{array}{l}\text { unde ascuțite } \\
\text { ocale } \\
\text { inter }\end{array}$ & $\begin{array}{l}\text { ipote ? } \\
\text { infecțioasă } \\
\text { (rotavirus) sau } \\
\text { metabolică } \\
\text { (defecte zinc) }\end{array}$ & favorabil & fenobarbital \\
\hline $\begin{array}{l}\text { \# Epilepsie } \\
\text { neonatală } \\
\text { familială } \\
\text { benignă }\end{array}$ & săptămâna 1 & $\begin{array}{l}\text { hipertonie și } \\
\text { apnee urmată } \\
\text { de manifestări } \\
\text { autonome, motorii } \\
\text { oculofaciale } \\
\text { și clonice ale } \\
\text { membrelor; 1-2'; } \\
\text { 20-30/zi }\end{array}$ & $\begin{array}{l}\text { tr } \\
\text { a国 }\end{array}$ & $\begin{array}{l}\text { gene ă?muta ții } \\
\text { gene canal potasiu } \\
\text { cu transmitere } \\
\text { autosomal } \\
\text { dominantă }\end{array}$ & $\begin{array}{l}\text { adesea remisie } \\
\text { între lunile 1-6 }\end{array}$ & $\begin{array}{l}\text { benzodiazepine } \\
\text { fenobarbital } \\
\text { fenitoină } \\
\text { leve a®etam }\end{array}$ \\
\hline $\begin{array}{l}\text { \& } \\
\text { Encefalopatie } \\
\text { epileptică } \\
\text { infantilă } \\
\text { timpurie } \\
\text { (Ohtahara) }\end{array}$ & $\begin{array}{l}\text { primele } 10 \\
\text { zile }\end{array}$ & $\begin{array}{l}\text { xi® } \\
\text { tonică a } \\
\text { trunchiului); } \\
\text { 1-10", } 10-300 / z i \\
\text { în veghe și somn; } \\
\text { ulterior hipotonie, } \\
\text { spas at@ ataxie }\end{array}$ & \begin{tabular}{l}
\multicolumn{1}{c}{ burst- } \\
suppression \\
con \\
veghe și somn
\end{tabular} & $\begin{array}{l}\text { adeseastructurală } \\
\text { (ex.defecte } \\
\text { migrare } \\
\text { neuronală), dar } \\
\text { și metabolică sau } \\
\text { gene ă? }\end{array}$ & $\begin{array}{l}\text { progresie spre } \\
\text { sindrom West } \\
\text { și apoi Lennox- } \\
\text { Gastaut; } 50 \% \\
\text { mortalitate } \\
\text { și } 50 \% \text { de } \\
\text { neurologic } \\
\text { permanent } \\
\text { sever }\end{array}$ & $\begin{array}{l}\text { benzodiazepine } \\
\text { fenobarbital } \\
\text { fenitoină } \\
\text { leve a®etam } \\
\text { topiramat } \\
\text { chirurgia } \\
\text { malformațiilor }\end{array}$ \\
\hline $\begin{array}{l}\text { \& } \\
\text { Encefalopatie } \\
\text { mioclonică } \\
\text { timpurie }\end{array}$ & $\begin{array}{l}\text { primele } 10 \\
\text { zile }\end{array}$ & $\begin{array}{l}\text { mioclonii membre } \\
\text { distal + crize focale } \\
+ \text { spasme infan } \\
\text { tonice }\end{array}$ & $\begin{array}{l}\text { similar cu } \\
\text { sindromul } \\
\text { Ohtahara, dar } \\
\text { mai mult în }\end{array}$ & $\begin{array}{l}\text { majoritatea } \\
\text { - metabolică } \\
\text { (hiperglicinemie } \\
\text { noncet ă, } \\
\text { lacidemie } \\
\text { me ă } \\
\text { etc.) }\end{array}$ & $\begin{array}{l}50 \% \\
\text { mortalitate în } \\
\text { primul an de } \\
\text { viață }\end{array}$ & $\begin{array}{ll}\mathrm{e} & \text { ă e } \\
\text { posibil } & \end{array}$ \\
\hline
\end{tabular}




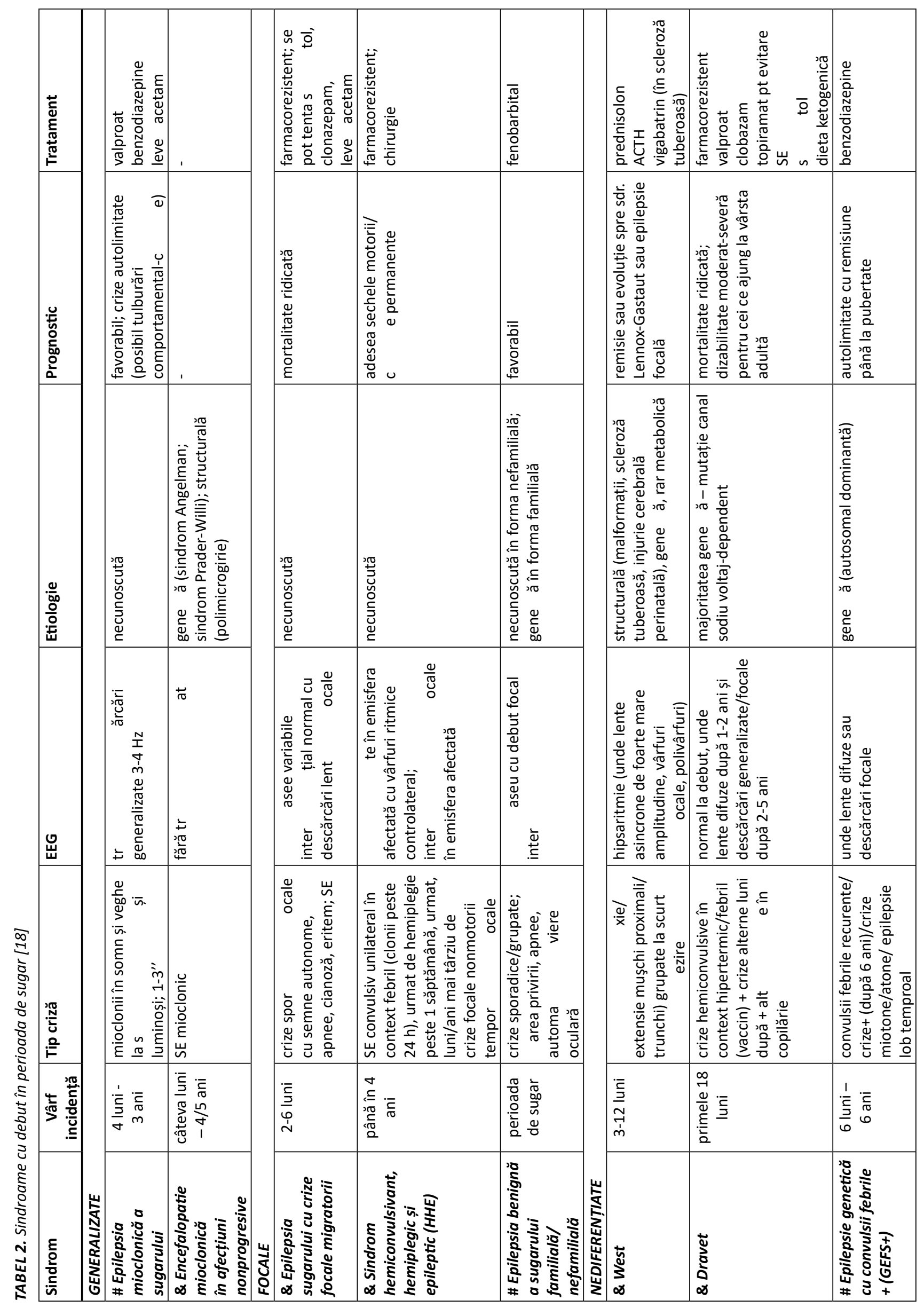




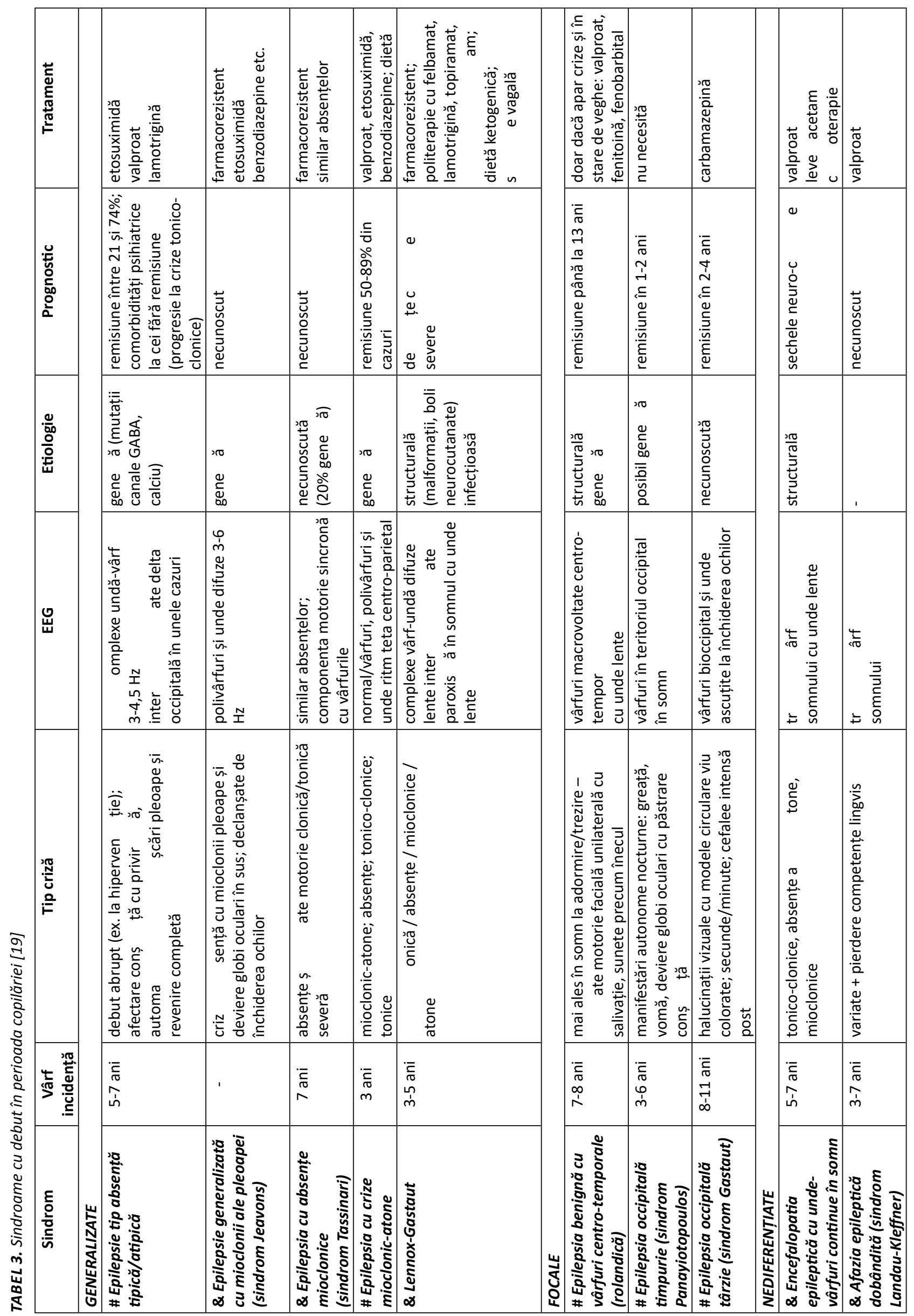




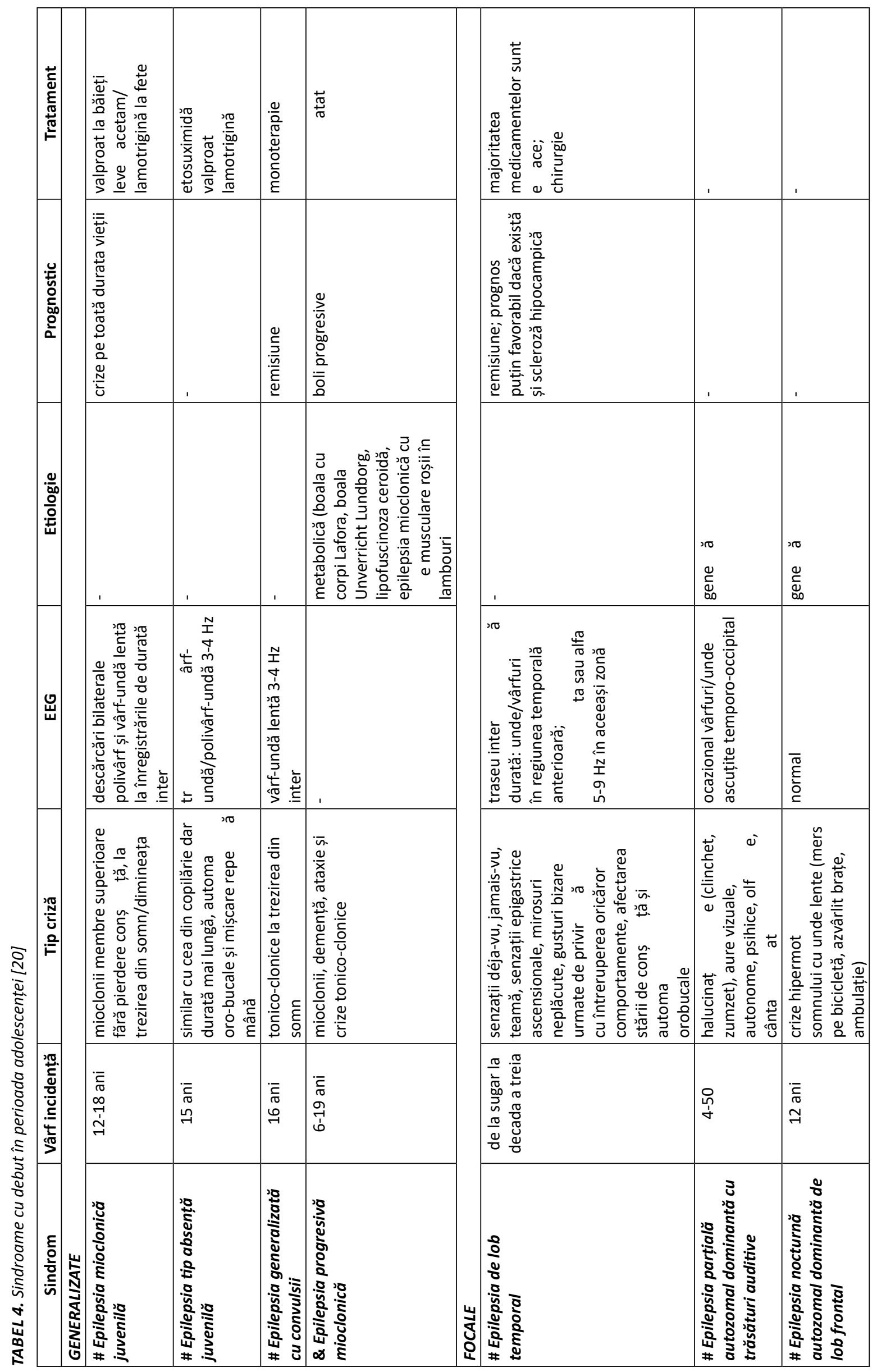


Dacă manifestările tip convulsii febrile sunt cele mai frecvente (și relativ benigne) tipuri de crize convulsive pe care un medic de familie le poate întâlni în practica curentă (asemănătoare epilepsiei, dar care nu sunt subsumate epilepsiei, dat fiind caracterul lor acut-provocat) și dacă manifestările sindromice ce tocmai au fost trecute în revistă sunt un melanj de benign și infaust, în marea lor majoritate nu foarte frecvente, la capătul grav al spectrului de forme și intensități se află starea de rău epileptic sau statusul epileptic (SE).

SE reprezintă una din cele mai comune urgențe neurologice în rândul populației pediatrice, cu o incidență ce atinge cele mai mari valori în rândul copiilor sub un an și care descrește progresiv cu vârsta. Majoritatea evenimentelor de tip SE par să debuteze la copii anterior sănătoși, în afara mediului spitalicesc, etiologia cea mai comună fiind febrilă/infecțioasă, urmată de alte etiologii simptomatic acute tip hipoglicemie, diselectrolitemii etc. [21].

Definiția clasică a SE include acele convulsii continue sau intermitente, fără revenire la starea mentală bazală, cu durata mai mare de 30 de minute, durată după care mecanismele compensatorii par a ceda în fața acidozei, hiperpotasemiei, hipertermiei și colapsului cardiocirculator. Este puțin probabil însă ca acele convulsii ce depășesc 5 minute să se oprească spontan, motiv pentru care depășirea în practica clinică a acestei durate este considerată a fi SE iminent, cu instituirea imediată a protocolului terapeutic cu scopul de a preveni prelungirea duratei crizei și injuria neuronală asociată. Studii epidemiologice au arătat faptul că mortalitatea pentru crizele cu durată între 10 și 29 de minute este în jurul valorii de $2,6 \%$, în timp ce mortalitatea pentru crizele de peste 29 de minute $s$-ar situa în jurul valorii de $19 \%$, forma amenințătoare de viață fiind, în primul rând, cea generalizat tonico-clonică. Alte forme din acest spectru sunt cele mioclonice, clonice, tonice sau tipurile nonconvulsivante cum ar fi cele generalizate tip absență sau cele focale, cu modificări prelungite de comportament sau de mentație, cu descărcări epileptiforme continue la nivelul traseului EEG [21]. În fapt, SE iminent (cu durata peste 5 minute) și cel net instalat (cu durata peste 30 de minute) reprezintă cel mai probabil un continuum, pragurile de 5 și 30 de minute fiind arbitrare și, în orice caz, derivate din studii pe cazuri de crize convulsive generalizate. Ceea ce este însă cert este faptul că, cu cât o criză durează mai mult, cu atât devine mai pretabilă la a se autoîntreține și mai rezistentă la tratament. Baza fiziopatologică a acestei evoluții este reprezentată de scăderea rapidă a receptorilor tip GABAa și de creșterea numărului de receptori NMDA postsinaptici funcționali. PostSE, copiii pot dezvolta recurențe, epilepsie sau disfuncții neurocognitive subtile (deficite neurologice focale, tulburări cognitive, tulburari comportamentale).

\section{CONCLUZII}

Manifestările epileptice reprezintă o patologie neurologică frecventă, cu potențial de evoluție severă, cu tabloul clinic diferit în populația pediatrică spre deosebire de adulți. Incidența crescută a manifestărilor se întâlnește în rândul grupelor de vârstă corespunzând sugarilor și copilăriei timpurii, precum și în rândul grupelor de vârstă de peste 50-60 de ani. Cea mai mare incidență se înregistrează în primul an de viață. Referitor la prevalența acestor manifestări, putem afirma existența unei prevalențe mici în rândul sugarilor și al copiilor, care prezintă o creștere la vârsta de adult tânăr, pentru ca mai târziu să scadă, descrescând în anii târzii.

Se descrie o variabilitate mare a manifestărilor clinice și a etiologiei epilepsiei în populația pediatrică. Sistematizarea acestor manifestări epileptice pe grupe de vârstă reprezintă un instrument deosebit de util în orientarea diagnosticului și instituirea unei intervenții terapeutice optime.

O mențiune specială este necesară în legătură cu convulsiile febrile, care, deși în afara spectrului epileptic prin natura acut-provocată a acestora, sunt, probabil, cele mai frecvente tipuri de crize convulsive pe care medicul de familie le-ar putea întâlni în rândul populației pediatrice.

\section{Mențiune}

Toți autorii au contribuit în mod egal la realizarea acestui articol.

Conflict of interest: none declared Financial support: none declared

\section{BIBLIOGRAFIE}

1. https://www.who.int/news-room/fact-sheets/ detail/epilepsy.

2. Pearl PL. Overview of Seizures and Epilepsy in Children. In Swaiman KF, Ashwal S, Ferriero DM (editors) Paediatric neurology: principles and practice, 6th edition. Philadelphia: Elsevier, 2018, pp 497-500.
3. Fiest KM, Sauro KM, Wiebe S, Patten SB, Kwon CS, Dykeman J, Pringsheim T, Lorenzetti DL, Jetté N. Prevalence and incidence of epilepsy: A systematic review and meta-analysis of international studies. Neurology. 2017;88(3):296-303.

4. Camfield P, Camfield C. Incidence, prevalence and aetiology of seizures and epilepsy in children. Epileptic Disord. 2015;17(2):117-23.

5. Devinsky O, Vezzani A, O'Brien TJ, Jette N et al. Epilepsy. Nat Rev Dis Primers. 2018;4:18024.

6. Mitchell WG et al. Behavioral, Cognitive and Social Aspects of Childhood Epilepsy. In Swaiman KF, Ashwal S, Ferriero DM 
(editors) - Paediatric neurology: principles and practice, 6th edition. Philadelphia:

Elsevier, 2018, pp 636-641.

7. Fisher RS, Cross JH, D'Souza C, French JA, Haut SR et al. Instruction manual for the ILAE 2017 operational classification of seizure types. Epilepsia. 2017;58(4):531542.

8. Trinka E. Classification of the epilepsies: Old wine in new skins? Webcast al Conferinţei de Neurologie de la Lisabona 2018 disponibil pe website-ul European Academy of Neurology (https://ean. conference2web.com/\#!resources/ classification-of-epilepsies), accesat la 14 august 2018.

9. Nordli DR Jr. Focal and Multifocal Seizures. In Swaiman KF, Ashwal S, Ferriero DM (editors) - Paediatric neurology: principles and practice, 6th edition. Philadelphia: Elsevier, 2018, pp 531-537.

10. Holmes GL. Generalized Seizures. In Swaiman KF, Ashwal S, Ferriero DM (editors) - Paediatric neurology: principles and practice, 6th edition. Philadelphia: Elsevier, 2018, pp 524-530.

11. Bailey RC, Ullrich NJ, Goodkin HP. Other Acquired Epilepsies: Trauma, Stroke, Tumors. In Swaiman KF, Ashwal S, Ferriero DM (editors) - Paediatric neurology: principles and practice, 6th edition. Philadelphia: Elsevier, 2018, pp, 590-593.

12. $1 \mathrm{LLAE}$ - International League Against Epilepsy (2018). Epilepsy Imitators. https:// www.epilepsydiagnosis.org/epilepsyimitators.html, accesat la 30 august 2018.

13. Plioplys S, LaFrance WC Jr. Pediatric Psychogenic Nonepileptic Seizures and Psychiatric Disorders. In Kenneth F Swaiman KF, Ashwal S, Ferriero DM (editors) - Paediatric neurology: principles and practice, 6 th edition. Philadelphia: Elsevier, 2018, pp 631-635.

14. Mirzaa GM, Yuskaitis CJ, Poduri A. Focal Structural Epilepsy. In Swaiman KF, Ashwal $S$, Ferriero DM (editors) - Paediatric neurology: principles and practice, 6th edition. Philadelphia: Elsevier, 2018, pp 583-589.

15. Pearl PL. Inherited Metabolic Epilepsies. In Swaiman KF, Ashwal S, Ferriero DM (editors) - Paediatric neurology: principles and practice, 6 th edition. Philadelphia: Elsevier, 2018, pp 594-599.

16. Seinfeld S, Shinnar S. Febrile Seizures. In Swaiman KF, Ashwal S, Ferriero DM (editors) - Paediatric neurology: principles and practice, 6 th edition. Philadelphia: Elsevier, 2018, pp 519-523.
17. Hani AJ, Mikati MA. Electroclinical Syndromes: Neonatal Onset. In Swaiman KF, Ashwal S, Ferriero DM (editors) Paediatric neurology: principles and practice, 6 th edition. Philadelphia: Elsevier, 2018, pp, 552-556.

18. Wirrell EC, Nickels KC.Electroclinical Syndromes: Infantile Onset. In Swaiman KF, Ashwal S, Ferriero DM (editors) Paediatric neurology: principles and practice, 6th edition. Philadelphia: Elsevier, 2018, pp, 557-568.

19. Tenney JR, Glauser T. Electroclinical Syndromes: Childhood Onset. In Swaiman KF, Ashwal S, Ferriero DM (editors) Paediatric neurology: principles and practice, 6 th edition. Philadelphia: Elsevier, 2018, pp, 569-575.

20. Harriott AM, Tatum WO. Electroclinical Syndromes: Adolescent Onset. In Swaiman KF, Ashwal S, Ferriero DM (editors) Paediatric neurology: principles and practice, 6th edition. Philadelphia: Elsevier, 2018, pp, 576-582.

21. Fernandez IS, Abend NS, Loddenkemper T. Status Epilepticus. In Swaiman KF, Ashwal $S$, Ferriero DM (editors) - Paediatric neurology: principles and practice, 6 th edition. Philadelphia: Elsevier, 2018, pp 543-551. 